\title{
THE INFLUENCE OF TAKING A PART TIME JOB TOWARDS STUDENTS' LEARNING MOTIVATION AT THE SEVENTH SEMESTER STUDENTS OF ENGLISH EDUCATION DEPARTMENT OF UIN ALAUDDIN MAKASSAR
}

\author{
Sitti Nurpahmi \\ Andi Mulyana Tamrin \\ English Education Department of UIN Alauddin Makassar \\ nurpahmi74@gmail.com \\ mulyananbana01@gmail.com
}

\begin{abstract}
The main objective of this research was to find out the influence of taking a part time job towards students' learning motivation at the seventh semester students of English Education Department. The researcher applied quantitative and qualitative descriptive method. The population of this research was the seventh semester students of English Education Department and the sample were students who took part time jobs in each class of the seventh semester students' academic year 2012 which consisted of 20 students. The data were collected through questionnaire and interview. The result of the data was indicated that there were positive influences of taking a part time job towards students' learning motivation. It was proven by the mean score of total number of all questions as 43.9 which was classified as very high. The result of interview was some students liked their part time jobs because they could be more experienced in teaching, could obtained money for their daily needs, and they said that there was influence of taking a part time job towards their learning motivation improvement. It was proven by the lists of students' GPA which the most were increase. The positive influences also from the hours of students' work which were not more than 20 hours per week where it was appropriate with the rule in Australia. Based on the result, the researcher concluded that taking a part time job has some influences especially in improving students' learning motivation.
\end{abstract}

KEYWORDS: Taking a part time job, Teaching English, Learning motivation.

\section{A. INTRODUCTION}

$\mathrm{J}$

ob is a work for which you receive regular payment (Oxford, 2008: 239). It is very important for people to find a job for buying and for paying all of the daily needs. Currently, there are many kinds of job and many ways to obtain it. The jobs have some rules which the people have to meet. In having a job, not only the people which have passed the graduation who can obtain a job, but also students can do it as well. The students who do not have enough money and want help her parents can do things between studying and working, or it is usually called taking a part time job.

Taking a part time job has become the phenomenon among university students. Some students make their mind up to continue their study to an university while having a part time job with some reasons. The economic factor is in the first rank as a reliable reason that 
students have to work in order that they can obtain money to pay for the tuition or just want to obtain more money to reduce the burden on parents. Other reasons which have enough roles are because of the students want to obtain experience, to broaden their relations or it just as a way to actualize themselves. Part time job activities are effective mean by which students who spend their lives commuting between home and school can engage on a casual basis with corporate society and the world of employment, and such as they can smooth the school to work transition, and provide good opportunities to implement career development through work experience.

Studying while working has a big influence especially for the students'learning motivation. Motivation itself is a process that starts with a psychological deficiency or need a drive that is aimed at a goal or incentive by Luthans in Pujadi (2002: 161). Furthermore, students' learning motivation can be defined as a condition in students' self which encourage and direct students' behavior to the objectives that they want to achieve in higher education. Taking a part time job is related to the students' learning motivation particularly if the job is relevant with their major, the students will be motivated and obtain a good score of their course. Li-Chen \& Wooster's in Kurniawati and Nurjannah (1979) said that university students whose job is relevant with the major which they have been chosen, can obtain a higher GPA (Grade Point Average) than university students who have a job which is not relevant with the major.

From the explanations above, the purpose of this research is to cognize whether there is influence of taking a part time job towards students' learning motivation or not. Taking a part time job specifically means here as a job which relevant with the major. Based on the researcher's experience, there are some students who take a part time job but the job does not give any impact to their score. In the contrary, students' knowledge which is relevant with the major is increase. Therefore, the researcher believes that students who take part time jobs which are relevant with the major will be motivated in learning process.

Taking a part job also has benefit to motivate the students who do not take part time jobs to do the same thing because studying while working can help the students not only in obtaining money but also in improving their learning motivation too. The student who takes a part time job can be an independent person and can be a good person in managing time between studying and working.

Although taking a part time job is good for students and has some positive impacts, but it also has negative impacts such as it can make students lazy to go to campus or to finish their study because they are too busy in working.

Furthermore, the research problem of this research was "How is the influence of taking a part time job towards students' learning motivation at the seventh semester students of English Education Department?". Then the research objective was to find out the influence of taking a part time job towards students' learning motivation at the seventh semester students of 
English Education Department. The researcher would like to focus on analyzing the data from students who took part time jobs which were relevant with the major especially on students who did studying while working, in this case while teaching, they were the seventh semester students of English Education Department of UIN Alauddin Makassar who were teaching English outside of the class.

\section{B. LITERATURE REVIEW}

The study as far as the researcher found about taking a part time job towards students' learning motivation, there are no same previous researches. However, there were some related researches that had been done.

Kathie (2008) conducted a research dealing with manajemen waktu ditinjau dari motivasi belajar pada mahasiswa bekerja. She found that there was a significant positive relationship between learning motivation in students who work and time management.

Agnes (2010) conducted a research dealing with bubungan antara status kerja, motivasi berprestasi, dan strategi belajar dengan prestasi akademik. In the research, she found that chievement motivation effect on students' academic achievement. In her research, she stated that there were two factors of students who were able to achieve a good performance. Those were the intelligence capabilities of students and the type of students' work in which the job which was relevant with students' major could improve the students' academic achievement.

Wang \& Chen (2012) conducted the research dealing with weighting the benefit of part time employment in college. They found the results of Analytic Hierarchy Process (AHP) analysis which showed that there were three benefits of part time job. There were from economic, social and learning dimension. They found that the most effective way of addressing the former is tutoring and general service, and the best way achieving the latter is also tutoring and general service. It can be conclude that taking a part time job has benefit in learning dimension and tutoring. It is a good job that may benefit the students fiscally, socially and academically.

Another finding by Norhayati, Steven and Mack (2012), they found the findings illustrate that part time students need appropriate learning support and guidance from the institution and instruction relate their work experiences to their academic learning, as well as to change their negative beliefs. They found the high score in positive belief suggests that most students agree their job knowledge and skills are important and useful to accomplish their academic tasks and vice versa.

Based on some researches which have been explained above, it shows that, taking a part time job may have a benefit in learning and teaching process. The researcher finally chose the research about the influence of taking a part time job towards the students learning motivation because the researcher believes that there are some influence of taking a part time job which is relevant with the students' major in this case is teaching, either 
Sitti Nurpahmi \& Andi Mulyana Tamrin, The Influence of Taking a Part Time Job ... .

it would be the positive or negative influence towards the students' learning motivation.

Part Time Job

Before the researcher discuss about the definition of part time job, first the researcher have to know about what job or work is. Work is something done by human beings for a specific purpose that is done in a way that is good and true (http://psikologiuntar.blogspot.com/2013/11/kerja-paruh-waktu-amelia705130067. html.). Humans need to work to survive. By working person will obtain the money.

The money which is obtained from the results of such work is used to meet humans' daily need. Part time job is a form of employment that carries fewer hours per week than a full-time job. Workers are considered to be part-time if they commonly work fewer than 30 or 35 hours per week (Part Time: 2013).

Based on the definition above, it can be concluded that part-time job is a job whose duties only during part of provision of working time or a normal working day, for example, the person appointed expert staff or other positions in a company that only works three days a week.

In this modern era, every individual need a job. There are many kinds of job in this world and one of them is part time job. Taking part time job are not only doing of the people who have another job, but also doing by the students in school and college too.

Taking a part-time job has become the phenomenon among university students, and some students follow this trend as well. Indeed, there are some advantages; however, there are also some disadvantages.

One of the advantages is that students can earn money. Taking a part-time job, in this point, students can pay a part of their living cost, and at the same time relieve their parents' burden. Some young people have to earn money on their own to pay the tuition while others just earn money to pay for their expenditure or satisfy their desire (Korotkykh: 2012).

In this material-oriented society, money is important and indispensable in our daily lives, so it's a beneficial advantage to work part time.

What's more, according to Korotkykh, another advantage is that students can acquire more experiences and polish their skills when taking part-time jobs. For example, if you enjoy teaching, working part-time as a tutor may help you improve your teaching skills and gain experiences. Different kinds of jobs require different skills; therefore, you are likely to gain experiences and improve skills as long as you devote yourself to working.

On the contrary, there are some disadvantages, too. For instance, you might be too exhausted after working to focus on your academic studying. It is inappropriate to skip classes or for obtain to do assignments due to part-time jobs because a student's duty is to try effort to do well at school. Korotkykh said that it is obvious that if you have a job, you automatically have less time to do the rest. 
Moreover, another disadvantage is that you might be deceived by the advertisement of part-time jobs. It is the dangerous part when finding or working part-time jobs.

To sum up, as the explanation above, there are some pros and cons when working part-time jobs. Consequently, all of us should think twice before taking part- time jobs. And when we take part-time jobs, we cannot ignore or for obtain our duties.

\section{Learning Motivation}

a. Learning

Learning is a process that must be undergone by all of human being. Learning process is not only happen in the class but also outside the class. According to Elias (2011), said that, Learning is a product of interaction. In learning process, learners might interact with teachers, tutor or instructors with content or with other people. Learning could be defined as a change in behavior or knowledge of an organism that is brought about through experiences, in interacting with the environment.

b. Motivation

Motivation is defined as the act or process of motivating; the condition of being motivating; a motivating force, stimulus, or influence; incentive; drive; something (such as a need or desire) that causes a person or student to act (Merriam- Webster, 1997 in Kaylene and Caroline). Motivation is an internal process that makes a person move toward a goal. It can encourage people to do an action, either that encouragement from themselves (internal) or it from outside of themselves (external). Motivation has an important role in learning. Motivation affects student's learning process. It increases a student's energy and activity level. Generally, more motivated students achieve higher levels of achievement. Motivation, like intelligence, can’t be directly observed.

1) The function of Motivation

According to Sardiman in Jayanti (2011) there are three functions of motivation; the first one is "as the power to make something", the second is "as the decider of human act", and the last is "as action selector". The researcher will explain those three function to gain clear understanding.

As the power to make something, it means that motivation in this case is the source of power which made human be motivated and doing anything to gain their goal. As a decider of human act, it gives direction for human to do their action or which way is the best to gain the aims. As action selector, it made human to select all steps which they should choose to reach the aims.

2) Kinds of motivation

Harmer in Sukatno (1993: 3-4) separates motivation in learning foreign language into two main categories: extrinsic motivation and intrinsic motivation. Extrinsic motivation is caused by a number of outside factors for example; they need to pass an exam, the hope of 
financial reward, of the possibility of future travel. While intrinsic motivation comes from inside the individual. Thus a person might be motivated by the enjoyment of the learning process itself by a desire to make them feel better.

3) Theory of Motivation

According to Herzberg in Riley (2005) there are two factors that can make people feel more motivated to do something, satisfaction and dissatisfaction. This theory explains two kinds of factors which is known as the motivation factors and hygiene factors. According to Frederick Herzberg, the motivating factors consist of achievement, recognition, work itself, responsibility, advancement, and possibility of growth, the researcher categorizes this factor into intrinsic motivation. Whereas, Hygiene factors includes relationship with the subordinate, personal life and so forth. The researcher categorized as an extrinsic motivation.

According to the Herzberg theory, cited in (Muhammad Aksan in Khairat, 2011: 10) research motivating factors is the human work, the successful that they are attained, gaining a chance, the development of carrier, and admitting from another. Hygiene factors are consist of an essential part in organization, the relationship between the individual with another, relationship with the peer, status, and job security (Shannon Riley, 2005:7).

Based on the explanation above, the researcher concluded that motivated students are they who have positive minds. They find the importance of learning themselves. They have needs for success, aspiration, and goal. They direct their effort to achieve the goal consistently. They are learning patiently although they have not understood what they learn. They have confidence that they will understand better.

\section{RESEARCH METHOD}

This research applied descriptive method. It was quantitative descriptive and qualitative descriptive research. The researcher collected the quantitative data from students by giving questionnaires to them and the data which were analyzed used qualitative were the data from the interview of students and those would be described by the researcher. This research was consisted of two variables. Taking a part time job as an independent variable/free variable, and students' learning motivation as a dependent variable.

This research, the seventh semester students of English Education Department had been selected as the population. The sample had been from some students who took part time jobs in each class of the seventh semester which were consisted of four classes, they were some students of PBI 1\&2, PBI 3\&4, PBI 5\&6 and PBI 7\&8. Technique sampling of this research which had been used was nonprobability sampling. In Nonprobability sampling technique, the researcher had applied purposive sampling.

Next, in this study the researcher used formulas to analyze the quantitative data that was from the questionnaire to found out the mean score or the average count of each questions and all the total numbers of the questions. The formulas of interval scale were: 
Table. I

The formula of interval scale for each question

\begin{tabular}{|c|c|c|c|}
\hline \multirow{2}{*}{ No } & \multicolumn{2}{|c|}{ Answer Score } & \multirow{2}{*}{ Answer Choice } \\
\cline { 2 - 3 } & Positive & Negative & Very high \\
\hline 1. & $4,21-5,00$ & $1,00-1,80$ & High \\
\hline 2. & $3,41-4,20$ & $1,81-2,60$ & Medium \\
\hline 3. & $2,61-3,40$ & $2,61-3,40$ & Low \\
\hline 4. & $1,81-2,60$ & $3,41-4,20$ & Very low \\
\hline 5. & $1,00-1,80$ & $4,21-5,00$ & \\
\hline
\end{tabular}

(Source: http://www.bekangdam-mulawarman.mil.id/artikel/50-publikasi-tesis)

Then, for the interval scale from all of the total number of questions, it could be seen that:

Table. II

The formula of interval scale for all of the questions

\begin{tabular}{|c|c|c|}
\hline No & Interval & Classification \\
\hline 1 & $42,1-50$ & Very high \\
\hline 2 & $34,1-42$ & High \\
\hline 3 & $26,1-34$ & Medium \\
\hline 4 & $18,1-26$ & Very low \\
\hline 5 & $10-18$ & \\
\hline
\end{tabular}

(Source: Made by the researcher)

In analyzing the qualitative data, the researcher had analyzed the result of the interview that had been done to the students by describing it. The data had been described to answer the questions about taking part time jobs. The data had been analyzed by the techniques as follows:

Data collection, the data had been collected from the students by recording it. The researcher had done the interview by phone to students, and then wrote the students' answer while recorded their voice to make the evidence strong.

Data reduction, the data had been reduced in this step. It had been selected and simplified by the researcher and only took the important data.

Data display, after collecting and reducing the data; the researcher had displayed the amassed data in organized and compressed.

Conclusion, the researcher had concluded the data in this step then described about the data and what the result of collecting data was.

\section{FINDINGS AND DISCUSSION}

Based on the results of distributing the questionnaire, the total of respondents who 
were ready to give their answers about their learning motivation and the answers of interview about their part time job which was relevant with their major and they had attained the requirement to be analyzed. The next process was giving score for the respondents' answer of each question of questionnaire and analyzed the answer of each question of the result of interview. For the questionnaire which the question was positive, if the answer was strongly agree (SS), the score was 5, and if the answer was strongly disagree (STS), the score was 1 and for the question which was negative, if the answer was strongly agree (SS), the score was 1 , and if the answer was strongly disagree (STS), the score was 5.

\section{Respondents' identity based on the class}

The data which were chosen from the students who were taking part time job which are teaching English. As the distributed questionnaire for 20 students as the respondents who were teaching of this research and after doing a sorting so that the total sheets of questionnaires which were delivered by email to be processed were 20 sheets.

Here was the respondents' identity according to the class:

Table. III

The respondents' identity based on the class

\begin{tabular}{|c|c|c|}
\hline Class & Frequency & Percentage (\%) \\
\hline PBI 1 \& 2 & 6 & $30 \%$ \\
\hline PBI 3 \& 4 & 10 & $50 \%$ \\
\hline PBI 5 \& 6 & 1 & $5 \%$ \\
\hline PBI 7 \& 8 & 3 & $15 \%$ \\
\hline Total & $\mathbf{2 0}$ & $\mathbf{1 0 0} \%$ \\
\hline
\end{tabular}

(Source: The processed primary data on May, 2015)

According to the table above, the number of the respondents who were teaching in class $1 \& 2$ were $6(30 \%)$, and the number of the respondents who were teaching in class 3 \& 4 were $10(50 \%)$, while the number of the respondents who were teaching in class 5 \& 6 were $1(5 \%)$, the number of the respondents who were teaching in the last class $7 \& 8$ were $3(15 \%)$. As that data, class $3 \& 4$ had greater number, and class $5 \& 6$ had the lowest number.

\section{Descriptive Analysis of the Research Data}

Here the researcher explained the result of the research about the influence of taking a part time job in improving the students' learning motivation of the seventh semester students of English Education Department.

The data which were analyzed were the data from the questionnaire about the students' learning motivation which was consisted of intrinsic motivation and extrinsic motivation. While the data from the interview were analyzed from each question. 
a. Students' Learning Motivation

1) Intrinsic Motivation

Here were the results of the deported questionnaire that had been sent by internet to the seventh semester students of English Education Department in UIN Alauddin Makassar about the students' learning motivation which were explained in two indicators, those were an encourage for learning and the desire in achieving the academic goals. It was consisted of six questions where four questions were positive and two questions were negative.

2) An encourage for learning

To know about the result of the questionnaires of this research from the seventh semester students of English Education Department about their encourage for learning, the indicator which was consisted of three questions could be seen in the tables as follow:

Table. IV

\section{The students' answer about learning before teaching}

(Taking part time job)

\begin{tabular}{|c|c|c|c|c|}
\hline No & Answer Category & $\begin{array}{l}\text { The number of } \\
\text { Respondents } \\
\text { (N) }\end{array}$ & Percentage (P) & $\begin{array}{l}\text { The average } \\
\text { count }(X)\end{array}$ \\
\hline \multirow[t]{6}{*}{1} & Strongly agree & 9 & $45 \%$ & \multirow{5}{*}{$X=\frac{\Sigma X}{N}$} \\
\hline & Agree & 11 & $55 \%$ & \\
\hline & Uncertain & 0 & $0 \%$ & \\
\hline & Disagree & 0 & $0 \%$ & \\
\hline & Strongly disagree & 0 & $0 \%$ & \\
\hline & Total & 20 & $100 \%$ & $\begin{array}{l}=\frac{89}{20} \\
=4.45\end{array}$ \\
\hline
\end{tabular}

(Source: The processed primary data on October, 2015)

The table above, the result of the influence of taking part time job towards students' learning motivation based on their answered about learning before teaching, 9 respondents $(45 \%)$ answered strongly agree, 11 respondents $(55 \%)$ answered agree, and no respondent $(0 \%)$ answered other categories. As the result by using mean formula, it was obtained the average count as 4.45 .

According to the interval scale of the average count, it could be concluded that the influence of taking a part time job towards students' learning motivation was very high. Meanwhile, the result of the research about the influence of taking a part time job towards students' learning motivation of the students' answer about more motivated to learning because know about ability and good method in teaching, it could be seen in the table $\mathrm{V}$ as follows: 
Sitti Nurpahmi \& Andi Mulyana Tamrin, The Influence of Taking a Part Time Job...

Table. V

The students' answer about more motivated to learning because know about ability and good method in teaching

\begin{tabular}{|c|c|c|c|c|}
\hline No & Answer Category & $\begin{array}{l}\text { The number of } \\
\text { Respondents (N) }\end{array}$ & $\begin{array}{l}\text { Percentage } \\
\text { (P) }\end{array}$ & $\begin{array}{l}\text { The average } \\
\text { count }(X)\end{array}$ \\
\hline \multirow[t]{7}{*}{2} & Strongly agree & 14 & $70 \%$ & \multirow{7}{*}{$\begin{array}{l}=\underline{94} \\
20 \\
=4.7\end{array}$} \\
\hline & & & & \\
\hline & Agree & 6 & $30 \%$ & \\
\hline & Uncertain & 0 & $0 \%$ & \\
\hline & Disagree & 0 & $0 \%$ & \\
\hline & Strongly disagree & 0 & $0 \%$ & \\
\hline & Total & 20 & $100 \%$ & \\
\hline
\end{tabular}

(Source: The processed primary data on October, 2015)

The table above, the result of the influence of taking part time job towards students' learning motivation based on their answers about more motivated to learning because know about ability and good method in teaching, 14 respondents (70\%) answered strongly agree, 6 respondents $(30 \%)$ answered agree, and no respondent $(0 \%)$ answered other categories. As the result by using mean formula, it was obtained the average count as 4.7.

According to the interval scale of the average count, it could be concluded that, the influence of taking a part time job towards students' learning motivation about more motivated to learning because know about ability and good method in teaching was very high. Next, to know the result of the research about the influence of taking a part time job towards students' learning motivation in their answer about not motivated to learning because must not know about the material before teaching, it could be seen in the table VI below:

Table. VI

The students' answer about not motivated to learning because must not know about the material before teaching

\begin{tabular}{|c|c|c|c|c|}
\hline No & Answer Category & $\begin{array}{c}\text { The number of } \\
\text { Respondents (N) }\end{array}$ & $\begin{array}{l}\text { Percentage } \\
\text { (P) }\end{array}$ & $\begin{array}{l}\text { The average } \\
\text { count }(X)\end{array}$ \\
\hline 3 & Strongly agree & 0 & $0 \%$ & $\Sigma \mathrm{X}$ \\
\hline & Agree & 0 & $0 \%$ & \multirow{5}{*}{$\begin{array}{l}=\frac{92}{20} \\
=4.6\end{array}$} \\
\hline & Uncertain & 0 & $0 \%$ & \\
\hline & Disagree & 8 & $40 \%$ & \\
\hline & Strongly disagree & 12 & $60 \%$ & \\
\hline & Total & 20 & $100 \%$ & \\
\hline
\end{tabular}

(Source: The processed primary data on October, 2015)

The table VI above, the result of the influence of taking part time job towards students' learning motivation based on their answered about not motivated to learning because must not know about the material before teaching (negative), 8 respondents (40\%) answered strongly 
disagree, 12 respondents $(60 \%)$ answered strongly disagree, and no respondent $(0 \%)$ answered other categories. As the result by using mean formula, it was obtained the average count as 4.6.

According to the interval scale of the average count of negative, it could be concluded that the influence of taking part time job towards students' learning motivation in the negative question about not motivated to learning because must not know about the material before teaching was very low.

b) The desire in achieving the academic goals

To know about the result of the questionnaires of this research from the seventh semester students of English Education Department of Tarbiyah and Teaching Science Faculty about their desire in achieving the academic goals, the indicator which was consisted of three questions could be seen in the tables below:

\section{Table. VII}

The students' answer about students' trust to reach for goal because the part time job relevant with the major

\begin{tabular}{|c|c|c|c|c|}
\hline No & Answer Category & $\begin{array}{c}\text { The number of } \\
\text { Respondents (N) }\end{array}$ & $\begin{array}{l}\text { Percentage } \\
\text { (P) }\end{array}$ & $\begin{array}{l}\text { The average } \\
\text { count }(X)\end{array}$ \\
\hline \multirow[t]{6}{*}{4} & Strongly agree & 10 & $50 \%$ & \multirow{6}{*}{$X=\frac{\Sigma X}{N}$} \\
\hline & Agree & 5 & $25 \%$ & \\
\hline & Uncertain & 4 & $20 \%$ & \\
\hline & Disagree & 1 & $5 \%$ & \\
\hline & Strongly disagree & 0 & $0 \%$ & \\
\hline & Total & 20 & $100 \%$ & \\
\hline
\end{tabular}

(Source: The processed primary data on October, 2015)

The table VII above, the result of the influence of taking part time job towards students' learning motivation based on their answer about trust to reach for goal because the part time job relevant with the major, 10 respondents (50\%) answered strongly agree, 5 respondents (25\%) answered agree, 4 respondents $(20 \%)$ answered uncertain, 1 respondent $(5 \%)$ answered disagree, and no respondent $(0 \%)$ answered strongly disagree. As the result by using mean formula, it was obtained the average count as 4.2.

According to the interval scale of the average count, it could be concluded that the influence of taking a part time job towards students' learning motivation based on the students' answer about students' trust to reach for goal because the part time job relevant with the major was high. Next, to know the result of the research about the influence of taking a part time job towards students' learning motivation in their answer about more motivated in reaching the desire because teaching gives the very useful experience, it could be seen in the table VIII below: 
Sitti Nurpahmi \& Andi Mulyana Tamrin, The Influence of Taking a Part Time Job...

Table. VIII

The students' answer about more motivated in reaching the desire because teaching gives the very useful experience

\begin{tabular}{|c|c|c|c|c|}
\hline No & Answer Category & $\begin{array}{c}\text { The number of } \\
\text { Respondents (N) }\end{array}$ & $\begin{array}{l}\text { Percentage } \\
\text { (P) }\end{array}$ & $\begin{array}{c}\text { The average } \\
\text { count }(X)\end{array}$ \\
\hline \multirow[t]{6}{*}{5} & Strongly agree & 16 & $80 \%$ & \multirow{6}{*}{$\mathrm{X}=\frac{\Sigma \mathrm{X}}{\mathrm{N}}$} \\
\hline & Agree & 4 & $20 \%$ & \\
\hline & Uncertain & 0 & $0 \%$ & \\
\hline & Disagree & 0 & $0 \%$ & \\
\hline & Strongly disagree & 0 & $0 \%$ & \\
\hline & Total & 20 & $100 \%$ & \\
\hline
\end{tabular}

(Source: The processed primary data on October, 2015)

The table VIII, the result of the influence of taking part time jobs towards students' learning motivation based on their answer about more motivated in reaching the desire because teaching gives the very useful experience, 16 respondents (80\%) answered strongly agree, 4 respondents $(20 \%)$ answered agree, and no respondent $(0 \%)$ answered other categories. As the result by using mean formula, it was obtained the average count as 4.8.

According to the interval scale of the average count, it could be concluded that the influence of taking a part time job towards students' learning motivation based on their answer about more motivated in reaching the desire because teaching gives the very useful experience that was very high. Next, to know the result of the research about the influence of taking a part time job towards students' learning motivation in their answer about students who are lasy in learning because the part time job prevents their studying in college, it could be seen in the table IX as follows:

Table. IX

The students' answer about students who are lazy in learning because the part time job prevents their studying in college

\begin{tabular}{|c|c|c|c|c|}
\hline No & Answer Category & $\begin{array}{l}\text { The number of } \\
\text { Respondents (N) }\end{array}$ & $\begin{array}{l}\text { Percentage } \\
\text { (P) }\end{array}$ & $\begin{array}{l}\text { The average } \\
\text { count }(X)\end{array}$ \\
\hline \multirow[t]{6}{*}{6} & Strongly agree & 0 & $0 \%$ & \multirow{6}{*}{$X=\frac{\Sigma X}{N}$} \\
\hline & Agree & 1 & $5 \%$ & \\
\hline & Uncertain & 1 & $5 \%$ & \\
\hline & Disagree & 6 & $30 \%$ & \\
\hline & Strongly disagree & 12 & $60 \%$ & \\
\hline & Total & 20 & $100 \%$ & \\
\hline
\end{tabular}

(Source: The processed primary data on October, 2015)

The table IX above, the result of the influence of taking part time job towards 
students' learning motivation based on their answer about students who are lazy in learning because the part time job prevents their studying in college (negative), no respondents $(0 \%)$ answered strongly agree, 1 respondent $(5 \%)$ answered agree, 1 respondent $(5 \%)$ answered uncertain, 6 respondents (30\%) answered disagree and 12 respondents (60\%) answered strongly disagree. As the result by using mean formula, it was obtained the average count as 4.45 .

According to the interval scale of the average count of negative, it could be concluded that the influence of taking part time job towards students' learning motivation in the negative question about students who are lasy in learning because the part time job prevent their studying in college was very low.

2) Extrinsic Motivation

Here were the results of the deported questionnaire that had been sent by internet to the seventh semester students of English Education Department in UIN Alauddin Makassar about the students' learning motivation in extrinsic motivation which would be explained in two indicators, those were a fluency of learning process and the influence of learning environment, and it was consisted of four questions where three questions were positive and one question was negative.

a) A fluency of learning process

To know about the result of the questionnaires of this research from the seventh semester students of English Education Department about their encourage for learning, the indicator consist of three questions and could be seen in the tables:

Table. X

The students' answer about always doing assignments from college because teaching does not prevent it at all

\begin{tabular}{|c|c|c|c|c|}
\hline No & Answer Category & $\begin{array}{c}\text { The number of } \\
\text { Respondents (N) }\end{array}$ & $\begin{array}{l}\text { Percentage } \\
\text { (P) }\end{array}$ & $\begin{array}{l}\text { The average } \\
\text { count }(X)\end{array}$ \\
\hline \multirow[t]{6}{*}{7} & Strongly agree & 9 & $45 \%$ & \multirow{6}{*}{$\begin{aligned} X & =\frac{\Sigma X}{N} \\
& =\frac{88}{20} \\
& =4.4\end{aligned}$} \\
\hline & Agree & 10 & $50 \%$ & \\
\hline & Uncertain & 1 & $5 \%$ & \\
\hline & Disagree & 0 & $0 \%$ & \\
\hline & Strongly disagree & 0 & $0 \%$ & \\
\hline & Total & 20 & $100 \%$ & \\
\hline
\end{tabular}

(Source: The processed primary data on October, 2015)

The table X, the result of the influence of taking part time jobs towards students' learning motivation based on their answer about always doing assignments from college because teaching does not prevent it at all, $9(45 \%)$ respondents answered strongly agree, 10 respondents $(20 \%)$ answered agree, 1 respondent $(5 \%)$ answered uncertain, and no respondent $(0 \%)$ answered other categories. As the result by using mean formula, it was obtained the average 
Sitti Nurpahmi \& Andi Mulyana Tamrin, The Influence of Taking a Part Time Job...

count as 4.4.

According to the interval scale of the average count, it could be concluded that the influence of taking a part time job towards students' learning motivation based on their answer about always doing assignments from college because teaching does not prevent it at all was very high. Next, the result of the research about the influence of taking a part time job towards students' learning motivation in their answer about the increasing of GPA although decided to take part time job could be seen in the table XI as follows:

Table. XI

The students' answer about the increasing of GPA although decided to take part time job

\begin{tabular}{|c|c|c|c|c|}
\hline No & Answer Category & $\begin{array}{c}\text { The number of } \\
\text { Respondents (N) }\end{array}$ & $\begin{array}{l}\text { Percentage } \\
\text { (P) }\end{array}$ & $\begin{array}{l}\text { The average } \\
\text { count }(X)\end{array}$ \\
\hline \multirow[t]{6}{*}{8} & Strongly agree & 3 & $15 \%$ & \multirow{6}{*}{$X=\frac{\Sigma X}{N}$} \\
\hline & Agree & 13 & $65 \%$ & \\
\hline & Uncertain & 4 & $20 \%$ & \\
\hline & Disagree & 0 & $0 \%$ & \\
\hline & Strongly disagree & 0 & $0 \%$ & \\
\hline & Total & 20 & $100 \%$ & \\
\hline
\end{tabular}

The table XI above, the result of the influence of taking part time jobs towards students' learning motivation based on their answer about the increasing of GP $A$ although decided to take part time job, 3 respondents (15\%) answered strongly agree, 13 respondents $(65 \%)$ answered agree, 4 respondents $(20 \%)$ answered uncertain, and no respondent $(0 \%)$ answered other categories. As the result by using mean formula, it was obtained the average count as 3.95 .

According to the interval scale of the average count, it could be concluded that the influence of taking a part time job towards students' learning motivation based on their answer about the increasing of GPA although decided to take part time job was high. Next, to know the result of the research about the influence of taking a part time job towards students' learning motivation in their answer about the assignments which did not do as the impact of taking a part time job, it could be seen in the table XII below:

Table. XII

The students' answer about the assignments which did not do as the impact of taking a part time job

\begin{tabular}{|c|c|c|c|c|}
\hline \multirow{2}{*}{ No } & Answer Category & $\begin{array}{c}\text { The number of } \\
\text { Respondents (N) }\end{array}$ & $\begin{array}{c}\text { Percentage } \\
(\mathbf{P})\end{array}$ & $\begin{array}{c}\text { The average } \\
\text { count }(X)\end{array}$ \\
\hline \multirow{2}{*}{9} & Strongly agree & 0 & $0 \%$ & \multirow{2}{*}{$\mathrm{x}=\frac{\Sigma}{\mathrm{N}}$} \\
\cline { 2 - 4 } & Agree & 1 & $5 \%$ & \multirow{3}{*}{} \\
\cline { 2 - 4 } & Uncertain & 2 & $10 \%$ & \\
\cline { 2 - 4 } & Disagree & 8 & $40 \%$ & \\
\hline
\end{tabular}




\begin{tabular}{|c|c|c|c|c|}
\hline Strongly disagree & 9 & $45 \%$ & $=\frac{85}{20}$ \\
\cline { 2 - 4 } & Total & 20 & $\mathbf{1 0 0 \%}$ & 4.25 \\
& & & \\
\hline
\end{tabular}

(Source: The processed primary data on October, 2015)

The table XII above, the result of the influence of taking part time job towards students' learning motivation based on their answer about the assignments which did not do as the impact of taking a part time job (negative), no respondent ( $0 \%$ answered strongly agree, 1 respondent (5\%) answered agree, 2 respondents $(10 \%)$ answered uncertain, 8 respondents $(40 \%)$ answered disagree and 9 respondents (45\%) answered strongly disagree. As the result by using mean formula, it was obtained the average count as 4.25 .

According to the interval scale of the average count of negative, it could be concluded that, the influence of taking part time job towards students' learning motivation in the negative question about the assignments which did not do as the impact of taking a part time job was very low.

b) The influence of learning environment

To know about the result of the questionnaires of this research from the seventh semester students of English Education Department about the influence of learning environment, the indicator which was consisted of one question could be seen in the table below:

Table. XIII

The students' answer about not excited to learn in the classroom of the college because the situation is different with the teaching room

\begin{tabular}{|c|c|c|c|c|}
\hline No & Answer Category & $\begin{array}{c}\text { The number of } \\
\text { Respondents (N) }\end{array}$ & $\begin{array}{l}\text { Percentage } \\
\text { (P) }\end{array}$ & $\begin{array}{l}\text { The average } \\
\text { count }(X)\end{array}$ \\
\hline \multirow[t]{6}{*}{10} & Strongly agree & 1 & $5 \%$ & \multirow{6}{*}{$X=\frac{\Sigma X}{N}$} \\
\hline & Agree & 0 & $0 \%$ & \\
\hline & Uncertain & 1 & $5 \%$ & \\
\hline & Disagree & 12 & $60 \%$ & \\
\hline & Strongly disagree & 6 & $30 \%$ & \\
\hline & Total & 20 & $100 \%$ & \\
\hline
\end{tabular}

(Source: The processed primary data on October, 2015)

The table XIII above, the result of the influence of taking part time job towards students' learning motivation based on their answer about not excited to learn in the classroom of the college because the situation is different with the teaching room (negative), 1 respondent $(5 \%)$ answered strongly agree, no respondent $(0 \%)$ answered agree, 1 respondent $(5 \%)$ answered uncertain, 12 respondents (60\%) answered disagree and 6 respondents (30\%) answered strongly disagree. As the result by using mean formula, it was obtained the average count as 4.1 . 
Sitti Nurpahmi \& Andi Mulyana Tamrin, The Influence of Taking a Part Time Job...

According to the interval scale of the average count of negative, it could be concluded that the influence of taking part time job towards students' learning motivation in the negative question about not excited to learn in the classroom of the college because the situation is different with the teaching room was low.

Based on the explanation above, it could be found the mean score or the average count of all the questions was 43.9. According to the interval scale from all of the total number of questions, it could be conclude that the influence of taking a part time job towards students' learning motivation at the seventh semester students of English education department of UIN Alauddin Makassar was very high.

\section{b. Taking part time job}

Based on the structural interview that, the researcher had done to 20 students at seventh semester from class PBI $1 \& 2$ to PBI $7 \& 8$ who were taking part time job which the interview was consisted of 11 questions, the result of the interview was all of 20 students were teaching English. The place where they taught was different, some of them teach on course place and private institute such JILC, INSTID, ARA Learning Center, BLC, RPC, MPM, Dimensi Private, brilliant college, SICIDA, and Khalifah dan Omar Group; on school such as in athirah, SMA Cokrominoto; and on university such as in AKPER Stelamonia and one of university program in UIN Alauddin Makassar that was PIBA.

The reasons why they taught were to increase their English knowledge, to obtained experience in teaching, to fill the free time and to obtain money. Then the research asked the question about how they used their salary and most of them answered that they used it for daily needs and for adding pockets money and other answered to save it. The answer of questions about how much they liked their job and all of them said that they liked it even some of them answered they really liked the job.

The researcher gave the questions which were related with the job and the students' study in college. The question was about whether the job prevent the students' study and 17 students of them answered that it did not prevent it at all, while 3 students answered it was a little annoying, but they could manage the time.

Other questions were about the positive and the negative impact of the teaching that they had done. Some of them answered that the positive impact of teaching was they knew how to deal with the students, they knew the students' characteristic so that they knew about the good method to use in class. With teaching, their communication ability and English knowledge could improve. They more were experienced and more confident in teaching; and they could obtain money automatically.

In the tenth question of structural interview, the researcher asked about whether or not there was any influence of teaching in improving their learning motivation and all of 20 respondents answered yes. One of them said, "Teach it means you learn twice" so that the answer was yes. 
The last question was about whether they thought that part time job was important for the students to be taken, and 4 respondents answered it was very important, 11 respondents answered important and 5 respondents answered important, but it was depend on situation.

In addition, the researcher asked about the time they worked, and all of the respondents answered that, they had the time to worked which was not more than 20 hours per week, and it was appropriate with the rule in Australia which the students could not work more than 20 hours per week (Erwin Hafid as previous graduated in Australia University).

The researcher also obtained lists of students' GPA (Grade Point Average) and the result was 13 students had the GPA which was increased, 4 students was decreased and 3 students was unchanged. It means that, their learning motivation had improved.

\section{E. CONCLUSION}

Based on the findings and discussion that had been explained, it could answer the problem about how the influence of taking a part time job towards students' learning motivation was at the seventh semester students of English Education Department. The researcher concluded that the influence of taking a part time job towards students' learning motivation at the seventh semester students of English Education Department which had been counted using formula and analyzed by questionnaires was very high and there were influences of taking a part time job towards the students' learning motivation at the seventh semester students of English Education Department of UIN Alauddin Makassar especially in improving the students' learning motivation.

\section{REFERENCES}

Arikunto, Suharsimi. Prosedur Penelitian: Suatu Pendekatan Praktik. Jakarta: Rikena Cipta, 2013. Apriyani, A. (2012). Faktor yang Memengarubi Kerja Parub Waktu. Retrieved on $9^{\text {th }}$ September (2015) from http://intisari-online.com/read/3-faktor-untuk- memilihfulltime-atau-freelance

Awing, Alwi. Analysing the Second Semester of English Education Department of UIN Alauddin Makassar Students' Perception toward the English Teachers' Competences in Teaching in Senior High School. Thesis. Makassar: UIN, 2015.

Cole, Michael S., Feild Hubert S. and Harris, Stanley G. Student Learning Motivation and Psychological Hardiness: Interactive Effects on Students' Reactions to a Management Class. Journal. Washington: Auburn University, 2004.

Echols, John M., and Hassan, Shadily. Kamus Inggris Indonesia. Jakarta: PT Gramedia, 1992. Elias, Tanya. Learning Analytics: Definitions, Processes and Potential. Journal. Creative Common Attribution, 2011. 
Sitti Nurpahmi \& Andi Mulyana Tamrin, The Influence of Taking a Part Time Job...

Ibrahim Norhayati, Steven A. Freeman. Mack C. Selley. Exploring the Impact of Work Experience on Part Time Student's Academic Success in Malaysian Polytechnics. Journal. Career and Technical Education Research. Iowa State University,2012.

Jayanti, Andi Evi. The Comparison of Using Authentic Materials and Text Book in Increasing the Seventh Grade Students' Motivation at MTs Madani Alauddin Paopao. Thesis. Makassar: UIN Alauddin, 2015.

Khairat, Ahmiranil. The Roles of Academic Advisors to the Students' Learning Motivation at the Seventh Semester Students of English Education Department at Alauddin State Islamic University of Makassar. Thesis. Makassar: UIN Alauddin, 2015.

Korotkykh, Polly. (2012). Retrieved on 9th November (2015). From https://polinakorotkykh.wordpress.com/2012/12/23/advantades-anddisadvantages- of-part-time-jobs-for-students/.

Kurniawati, Agnes Fibriana and Nurjannah. Hubungan Antara Status Kerja, Motivasi Berprestasi dan Strategi Belajar dengan Prestasi Akademik. Journal. Volume 11, No. 2. Palembang: STBA Methodist, 2010.

Kusuma, Kathie Purnamasari. Manajemen Waktu Ditinjau dari Motivasi Belajar pada Mahasiswa Bekerja. Thesis. Semarang: Universitas Katolik Soegijapranata, 2008.

Oxford. Oxford Learner's Pocket Dictionary: Fourth Edition. Oxford: Oxford University Press, 2008.

Part Time. (2013). Retrieved on 9th September (2015). From http://en.wikipedia.org/wiki/Part-time.

Pujadi, Arko. Faktor-faktor yang Mempengarubi Motivasi Belajar Mahasiswa: Studi Kasus Pada Fakultas Ekonomi Universitas Bunda Mulia. Journal. Jakarta: Universitas Bunda Mulia, 2007

Putra, Arsana. 2013. Retrieved on 17th October (2015). From http://www.bekangdammulawarman.mil.id/artikel/50-publikasi-tesis Retrieved on 9th September (2015). From http://psikologi- untar.blogspot.com/2013/11/kerja-paruh-waktu-amelia705130067.html.

Riley, Shannon. Herşberg's Two-Factor Theory in Motivation Applied to the Motivational Technique within Financial Institution. Journal. Honors College: 2005

Risda. Pengarub Tingkat Pendidikan Orang Tua Terbadap Motivasi Belajar Siswa MI Mubammadiyah 6 Syubada Kota Makassar. Skripsi. Makassar: UIN Alauddin, 2014.

Sugiyono. Metode Penelitian Kuantitatif, Kualitatif dan R\&D. Bandung: Alfabeta, 2014.

Sugiyono. Statistika Untuk Penelitian. Bandung: Alfa Beta, 2012.

Sukatno. Improving Students' Learning Motivation and Listening Proviciency Through Power Point (An Action Research at SMAN I Girimarto in 2006/2007 Academic Year). Thesis. Surakarta: Sebelas Maret University, 2008.

Wang, Chin-Fah and Chen, Shan-Hua. Weighting the Benefit of Part-Time Imployment in College: 
Perspectives from Indigenous Undergraduates. International Education Studies. Volume 6, No. 1, 2013.

Williams, Kaylene C., and Caroline C. Williams. Five Keys Ingredients for Improving Student Motivation. Journal. California: California State University. 